\title{
Features of the Development of the Digital Educational Environment in Russia
}

Ekaterina A. Ilyina ${ }^{1}$, Anna V. Shchiptsova ${ }^{2}$, Igor E. Poverinov ${ }^{3}$, Svetlana V. Grigoreva ${ }^{4}$, Nadezhda K. Gorshkova ${ }^{5}$ \& Pavel A. Fisunov ${ }^{6}$

${ }^{1}$ I.Y. Yakovlev Chuvash State Pedagogical University, Department of Economics, Management and Law, Cheboksary

${ }^{2}$ I.N. Ulyanov Chuvash State University, Department of Computer Engineering, Cheboksary, Russia

${ }^{3}$ I.N. Ulyanov Chuvash State University, Department of Philosophy, Sociology and Pedagogy, Cheboksary, Russia

${ }^{4}$ Moscow State University of Civil Engineering (National Research University), Department of Information Systems, Technologies and Automation in Construction, Moscow, Russia

${ }^{5}$ Cheboksary Professional College named after I.N. Nikolsky, Department of Management of Educational and Methodical Work, Cheboksary, Russia

${ }^{6}$ Chuvash State Agricultural Academy, Department of Mathematics, Physics and Information Technologies, Cheboksary, Russia

Correspondence: Ekaterina A. Ilyina, I.Y. Yakovlev Chuvash State Pedagogical University, Department of Economics, Management and Law, Cheboksary. E-mail: fiuip@mail.ru

Received: July 17, 2019

doi:10.5430/ijhe.v8n7p121
Accepted: October 10, 2019

Online Published: October 28, 2019

\begin{abstract}
Goal of the investigation: This article aims to distinguish the characteristics of the development of the digital educational environment in Russia in the context of the global digitalization process, and to identify threats to information security. Methodology: The leading method for studying this problem is a comparative analysis of the level of evolution of the digital administration in various nations of the world, which passes to comprehensively estimate the obstacle of receiving the learning and informative space as a portion in the sustainable expansion of the Russian economy. Results: The authors revealed the peculiarities of the Russian "digitalization" management system, which is still distinguished by spontaneity and the lack of a coordinated action program on the part of the state. It was revealed that Russia has the necessary potential for the further development of the digital economy: the scientific and intellectual base, a good level of secondary and higher technical education. The article substantiates the results of the development of the Russian digital educational environment: a data source (portal) has been created that is convenient to all levels of residents and stores each user with entrance to online classes for all levels of training and online support for mastering general education subjects; an infrastructure has been created to train teachers and administrative staff, to spread the experience of introducing successful methods and practices of online learning, to track the dynamics of creating a digital educational environment; and a system of advanced training for teachers in the development, use and examination of online courses has been created. Applications of this study: The materials of the article can be useful to relevant state and economic institutions for the formation of a mechanism for informatization of the country's development management system and education in particular, which is part of certain development strategies and programs; researchers of socio-economic processes associated with the development of the information society and the economy, and the increasing distribution of digital data processing technologies. The analysis of the digitalization process in the country and the world allowed us to identify problems that require close attention and finding solutions for the implementation of project activities for the formation of a modern digital educational environment in the Russian Federation. Novelty/Originality of this study: The novelty and originality of the study lies in the fact that for the first time it offers a comprehensive approach to assessing the specifics and factors of the digitalization process in the educational space of the country, developing mechanisms to reduce threats to information security by developing a system for identifying users, technical controls, and improving the legislative framework.
\end{abstract}

Keywords: digitalization, digital economy, threats and risks of digitalization, digital technologies 


\section{Introduction}

The term "digital economy" was adopted in the world community to denote economic activity, "in which the key factor of production is digital data, processing large volumes and using the result of analyzing them" allows to increase "the efficiency of various types of production, technology, equipment, storage, sales, delivery of goods and services" (Petrovskaya et al., 2016; Keshelava, 2017; Zaitseva et al., 2017; Merkulova et al., 2018; Masalimova et al., 2019; Bąk et al., 2019; Sailaukyzy et al, 2018).

As a result of the digitalization of economic activity, the task appeared to train personnel for the new economy. In turn, following the adoption of the term "digital economy", other terms related to this type of economic relations, including "digital education", "digital literacy", etc. were introduced into a wide range of topics (Vayndorf-Sysoeva \& Subocheva, 2018). According to the approach to the definition of "digital educational environment", designated by the expert of the League of Education, M.E. Kushnir (2017), is an open set of information systems designed to support various tasks of the educational process. Digital educational environment is able to provide access to electronic educational resources, electronic library systems, conduct online classes, record the progress and results of educational activities, etc.

For the Russian economy, the trend of digitalization is associated with serious challenges, since the issues of forming a digital economy become for Russia questions of its national security and competitiveness on the world market (external challenges), as well as questions of the level and quality of life of the Russian population (internal challenges). Russia's lagging behind the pace and scale of digitalization from developed countries can lead to the country being aloof from scientific and technological progress; Russian economy (Vinogradova et al., 2018; Khalin \& Chernova, 2018; Khusainova et al., 2018; Usak \& Masalimova, 2019; Martins et al, 2018; Rasooli \& Abedini, 2017; Puspitasari et al, 2019).

\section{Research Methodology}

\subsection{Research Methods}

In the process of research, a complex of mutually complementary methods was used, theoretical and empirical general scientific methods were used.

Theoretical methods contributed to the clarification, systematization of statistical, scientific and pedagogical facts used for conclusions, conclusions; projections of the concept of "digital educational environment" into the problem field of digitalization of the national economy and the education system.

Analysis and synthesis allowed to identify the structural elements of the educational space, then, combining them together, to consider the selected methodological, didactic, informational and program components of the educational environment in their unity, to present a system of sources, factors and principles of the formation and development of the digital educational environment.

On the basis of the historical and logical method, the objective process of the development of society, on the basis of progressive technologies, the mechanism for the formation of the digital economy has been revealed.

The induction method was used in the synthesis of economic, social facts in order to organize research work on testing the model of a modern digital educational environment. On the basis of the deduction method, a process was developed to derive a set of basic concepts that form the basis of the requirements and recommendations for the creation, quality assessment and application of the digital educational environment.

Empirical methods created the basis for the subsequent resolution of the problem of the development of the digital educational environment in Russia by developing a set of theoretical and practical requirements and recommendations for creating, assessing the quality and application of the digital educational environment, scientifically reviewing the results of the activities of subjects of the educational process, studying and systematizing the accumulated experience of types of economic activity.

Among the formalized methods of working out scientific, statistical, pedagogical documentation, content analysis was used, which implied textual analysis of periodicals, textbooks and dissertations.

\section{Results}

\subsection{The Digitalization Process in the World}

The program "Digital Economy of the Russian Federation" was approved on July 28, 2017, whereas similar programs in countries that hold leading positions today were developed much earlier. 
It is also worth noting that most of the leading states have a specially created body - the central committee on digitalization, which sets the general vector of development in this area. In Germany, there is a specialized committee under the parliament, which is composed of representatives from various ministries responsible for the development and implementation of the basic principles of digital society regulation.

For example, in Saudi Arabia, a plan for "digitalization" of the state was formulated in 2005 on the joint initiative of the king and individual government agencies. In order to implement it, the organization Yesser was created, whose structure includes a manager and supervisory committees consisting of members of ministries and specialized commissions. To control the implementation of the program, a project office has been formed, responsible for coordination and exchange of experience between departments.

In Australia, in addition to a single centralized body under the government of each territory (state), the position of director of digitalization (Chief Digital Officer - CDO) was introduced, authorized for the implementation of the central program in the territory entrusted to it. Along with this, a separate headquarters of the CDO is functioning, which, within the framework of the central program of digitalization, forms and implements its own strategy for the development of the digital economy.

Of course, competitive advantages are acquired by countries with advanced technological developments. It is for this reason that "Digitalization" is one of the priorities for the development of the Russian economy. A program is being developed to create a new type of economy, "aimed at creating conditions for the development of a knowledge society in the Russian Federation, improving the well-being and quality of life of our citizens by increasing the availability and quality of goods and services produced in the digital economy using modern digital technologies raising awareness and digital literacy, improving the availability and quality of public services for citizens, as well as security both within the country and beyond beyond"

Table 1. The value of the information and communication technology (ICT) development index for 2008-2017 in countries around the world

\begin{tabular}{|c|c|c|c|c|c|c|c|c|}
\hline \multirow[b]{2}{*}{ Indicators } & \multicolumn{8}{|c|}{ Years } \\
\hline & 2008 & 2010 & 2011 & 2012 & 2013 & 2015 & 2016 & 2017 \\
\hline $\begin{array}{c}\text { Number of countries } \\
\text { participating in the ranking }\end{array}$ & 152 & 166 & 157 & 166 & 166 & 175 & 176 & 176 \\
\hline $\begin{array}{c}\text { The largest, first place in the } \\
\text { ranking }\end{array}$ & 7,8 & 8,64 & 8,51 & 8,81 & 8,86 & 8,78 & 8,8 & 8,98 \\
\hline $\begin{array}{l}\text { The growth rate of the ICT } \\
\text { development index of the } \\
\text { leading countries }\end{array}$ & - & 1,108 & 0,985 & 1,035 & 1,006 & 0,991 & 1,002 & 1,020 \\
\hline $\begin{array}{l}\text { Russia (in brackets the place } \\
\text { of Russia in the rating is } \\
\text { indicated) }\end{array}$ & $\begin{array}{l}4,42 \\
(49)\end{array}$ & $\begin{array}{l}5,57 \\
(46)\end{array}$ & $\begin{array}{l}5,94 \\
(38)\end{array}$ & $\begin{array}{l}6,48 \\
(41)\end{array}$ & $\begin{array}{l}6,70 \\
(42)\end{array}$ & $\begin{array}{l}6,79 \\
(42)\end{array}$ & $\begin{array}{l}6,91 \\
(43)\end{array}$ & $\begin{array}{l}7,07 \\
(45)\end{array}$ \\
\hline $\begin{array}{l}\text { The growth rate of the ICT } \\
\text { development index in Russia }\end{array}$ & - & 1,260 & 1,066 & 1,091 & 1,034 & 1,013 & 1,018 & 1,023 \\
\hline $\begin{array}{c}\text { The smallest, last place in the } \\
\text { ranking }\end{array}$ & 0,79 & 0,88 & 0,93 & 0,93 & 0,96 & 1 & 0,89 & 0,96 \\
\hline
\end{tabular}




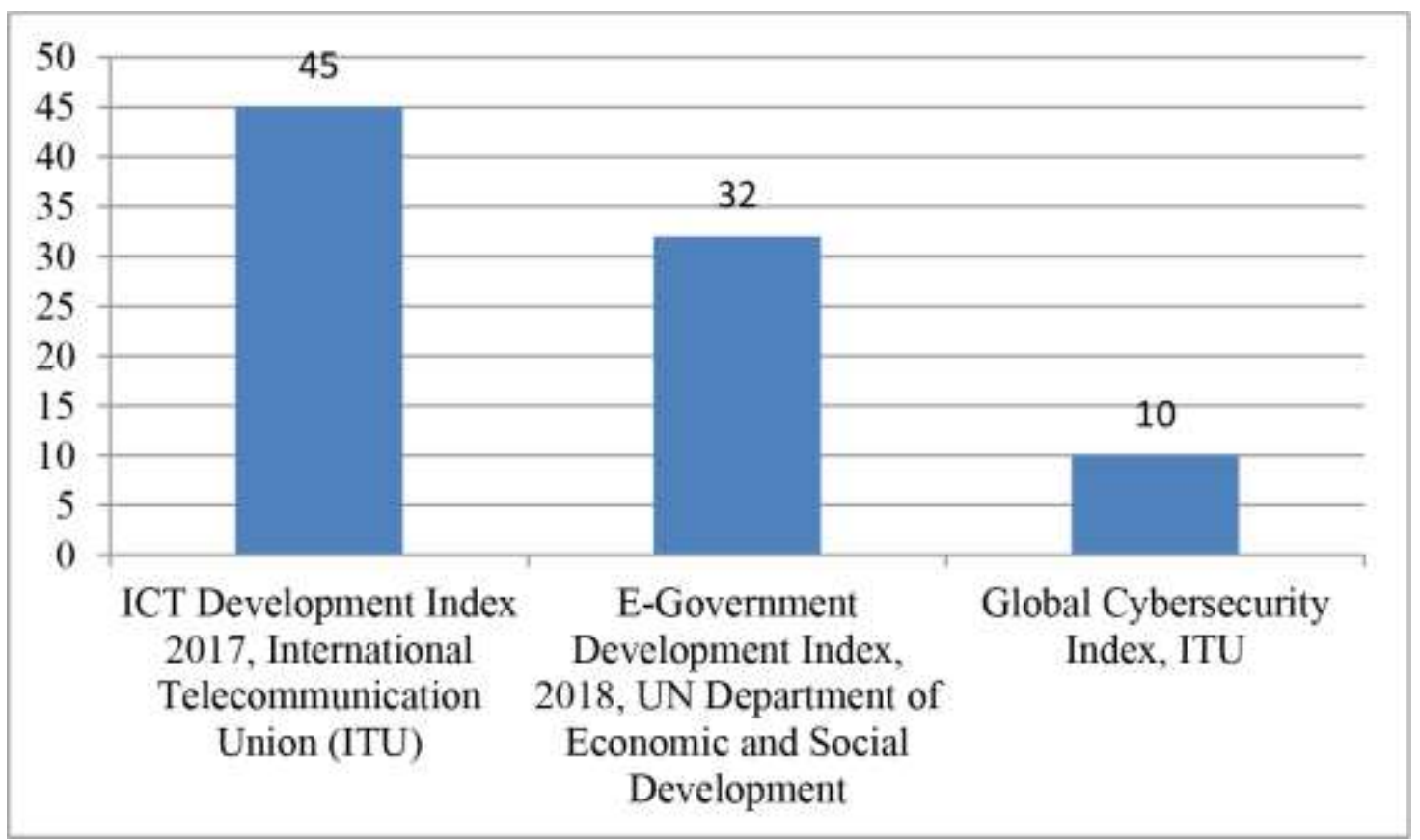

Figure 1. Russia's place in the world ratings of the digital economy

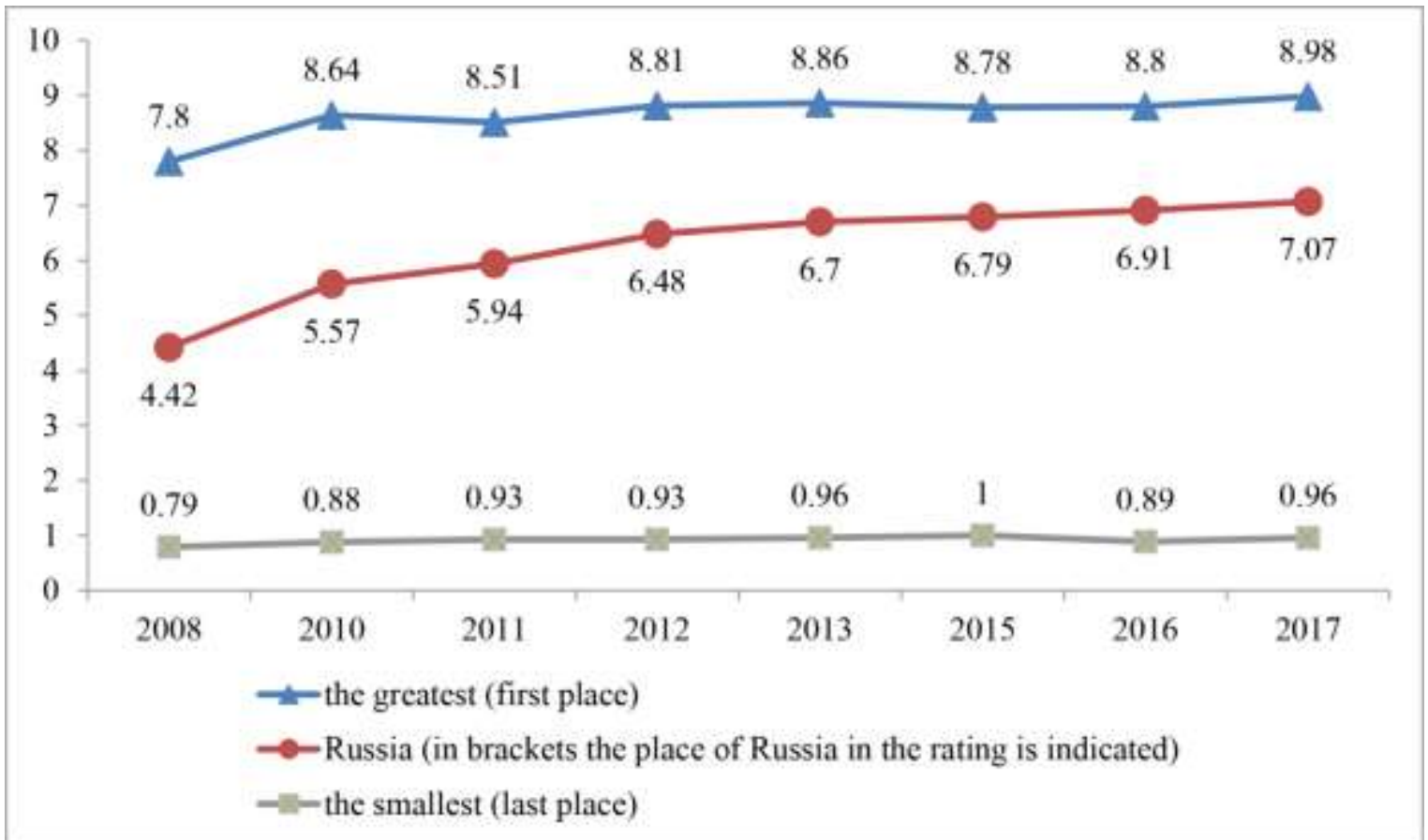

Figure 2. The value of the ICT development index (Source: ITU data) (Indicators of the digital economy, 2018)

The top 10 countries in terms of ICT development for 2017 include: Iceland, Republic of Korea, Switzerland, Denmark, United Kingdom, Hong Kong (China), Netherlands, Norway, Luxembourg, Japan.

The main reasons for the lag in the development of the digital economy of Russia from the leading states are the insufficient elaboration of the regulatory framework and conditions for doing business, the relatively low innovation activity of Russian enterprises. Moreover, the achievement of leadership positions is complicated by the fact that the technological base and digital markets were created mainly abroad, where Russia initially took the place of the buyer. In contrast to the leaders, the Russian digitalization management system is still distinguished by spontaneity, the lack of a coordinated action program on the part of the state, when market participants independently develop innovative activities, which, ultimately, is not due to the systematic nature of initiatives. 
One of the indicators of infrastructure development and ICT accessibility is the number of fixed broadband Internet subscribers per 100 population and the number of mobile broadband Internet subscribers per 100 population. The number of fixed broadband Internet subscribers per 100 population and the number of mobile broadband Internet subscribers per 100 population have an increasing trend. Information on the dynamics of infrastructure development and ICT accessibility for the period 2012-2017 for the Russian Federation is presented in Figure 3.

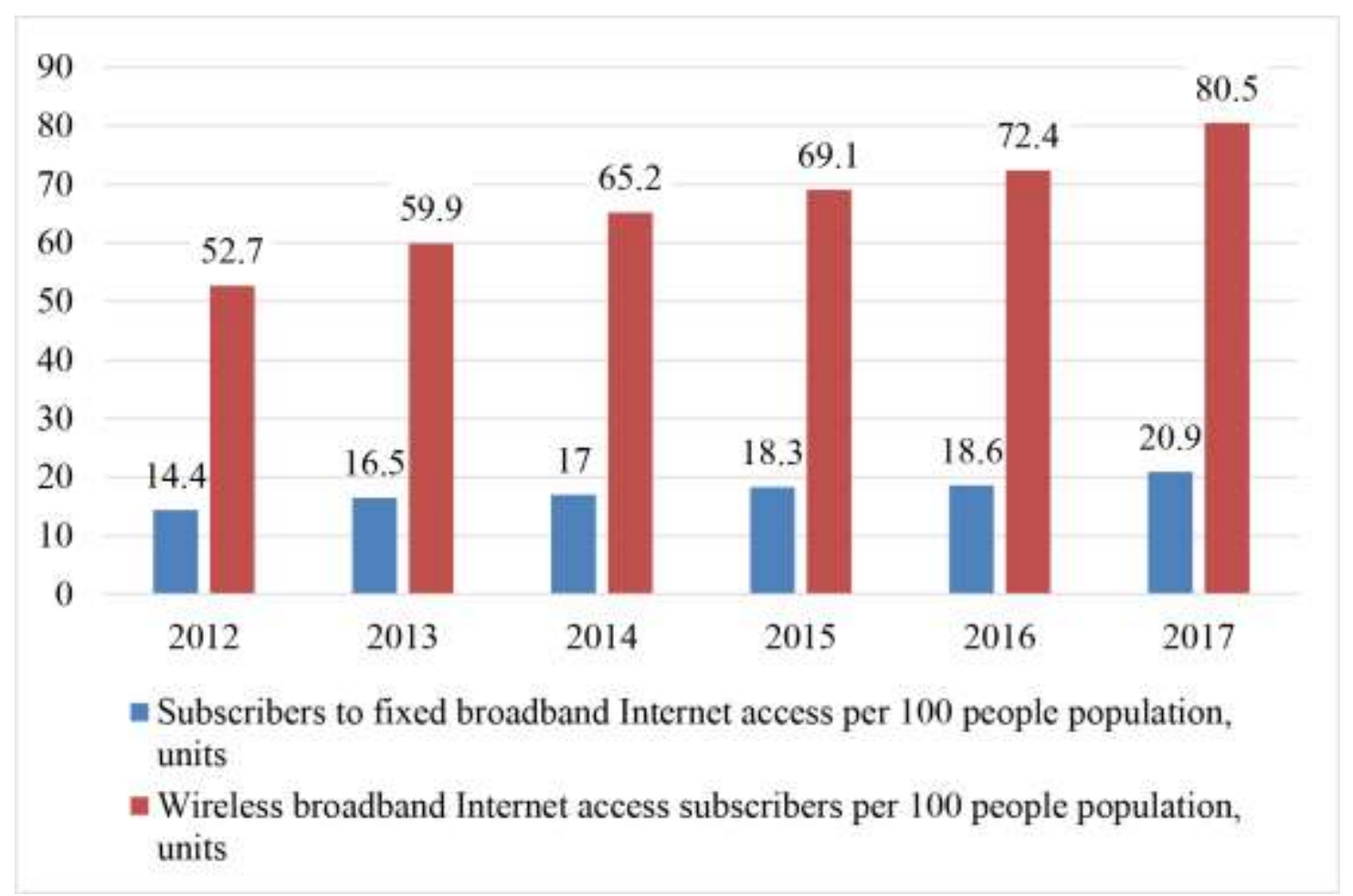

Figure 3. Dynamics of development of ICT infrastructure and availability from 2012 to 2017, the number per 100 people. Population

Source: (Monitoring of the information society development in the Russian Federation, 2018)

One of the essential obstacles of the improvement of the information infrastructure of Russia is the "digital inequality" of the regions. So, if the provision of services of broadband access for residents of megalopolises (Moscow and St. Petersburg) is about 75\%, in rural households it is about 30\%, and in some localities it is less than $10 \%$. The main reasons for this situation are objective. Due to the colossal territory and low population density in certain regions, the construction of high-length transport networks and modern access networks require significant investments from telecom operators.

\subsection{Digitalization Programs in Russia}

Despite the fact that recent statistics do not allow to fully judge the effectiveness of initiatives developed and implemented, it is believed that by 2025 the volume of the digital economy will increase threefold to 9.6 trillion. rub. Already, we can note some positive changes.

According to the research of the Russian Association of Electronic Communications (RAEC), currently about 2.3 million people are employed in the Internet industry. At the same time, the Runet's audience already amounts to about 90 million people, which corresponds to about $71 \%$ of the population of the Russian Federation. Among other things, large digital companies were created, some of which were able to reach the international level, among them: Tinkoff Bank is the first bank in Russia that does not have branches and carries out all transactions via mobile phone or the Internet; Yandex search engine and Internet portal; Mail.ru mail service; Avito ad service; VKontakte social network, etc. Large digital infrastructure projects are being implemented, such as a single procurement information system, a public services portal, a single medical information and analytical system (EMIAS), an Active Citizen portal, etc. (Grebenkina, 2018a).

It should be noted that Russia has the necessary potential for the further development of the digital economy: the scientific and intellectual base, a good level of secondary and higher technical education. However, in order to 
achieve targets in the field of digitalization, special attention should be paid to funding applied research, digital projects, mastering new technologies, increasing the innovative activity of enterprises, additional education and retraining of employees with regard to improving technologies, increasing competition and developing digital infrastructure. Currently, the lion's share of the export of IT services in the Russian Federation is not accounted for by licensed software, but by the development of individual solutions for large foreign enterprises that receive the greatest profits by selling final products. Our country's transition to the production of high value added end products for exports will accelerate the growth rate of the digital economy. The digital transformation of the economic and social sectors is presented in Figure 4.

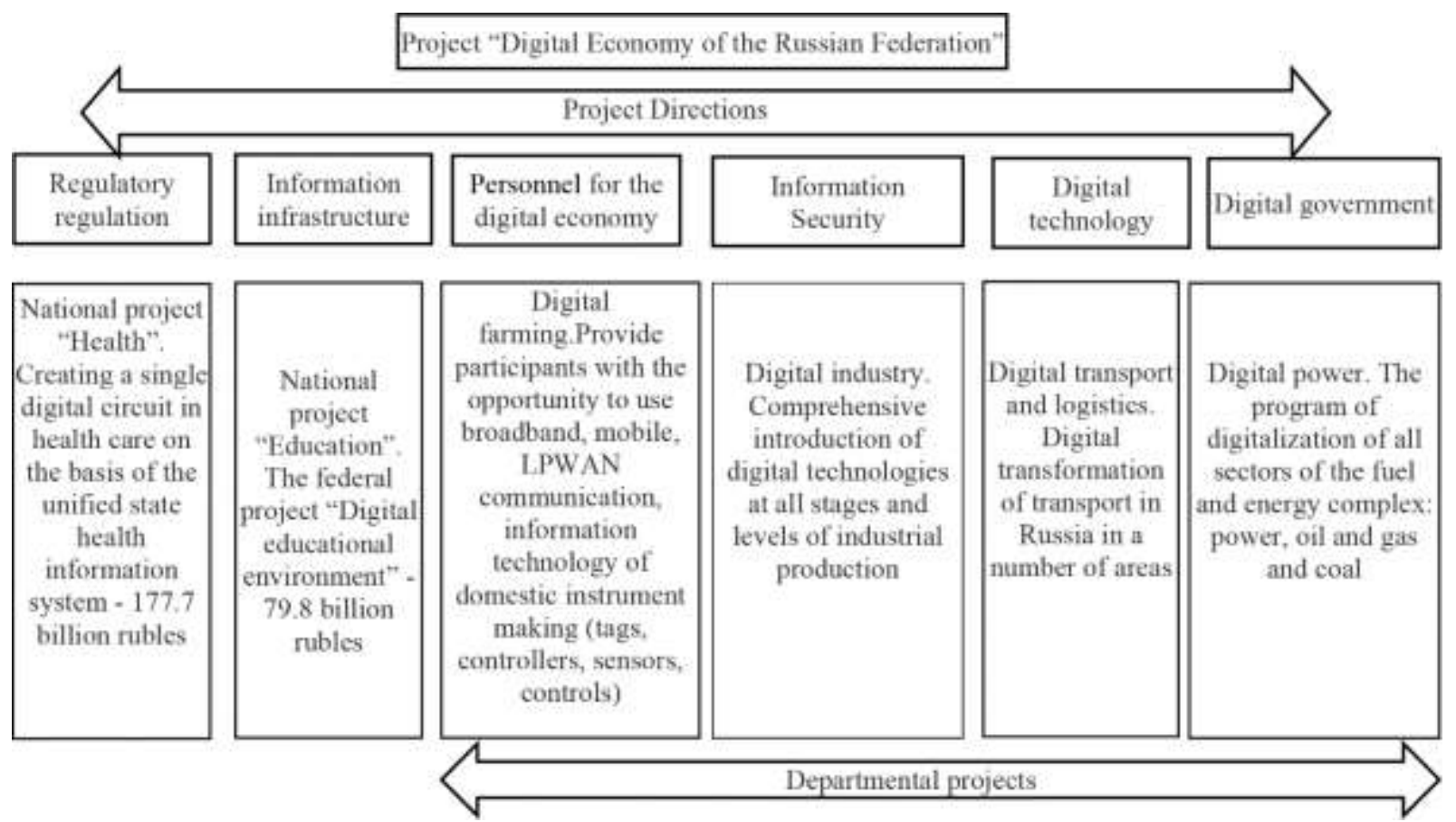

Figure 4. The digital transformation of the economic and social sectors

The penetration of information technologies in all sectors of the economy and social sphere is reflected in various areas of activity of organizations. For a stable position of organizations in the market in a digital economy, they need to introduce information environments. The introduction of the digital environment will facilitate the management of the organization, optimizes information flows (Grigorieva, 2018).

\subsection{Development of Digital Educational Environment in Russia}

In order to develop the information society, the state creates conditions for creating a knowledge space and providing access to it, improving knowledge dissemination mechanisms, their application in practice in the interests of each individual and the society as a whole (The decree of the President of the Russian Federation, 2017). Creating a modern innovation system of Russian education that meets the needs of the domestic economy is a priority for the development of the country (Kuzmin, 2016).

Improving the system of training qualified personnel and conducting interdisciplinary research and development demanded by the digital economy is a serious complex task that universities face (Shchiptsova, 2018).

The paragraph 4.5 of the Federal project "Personnel for the Digital Economy" of the Passport of the National Program "Digital Economy of the Russian Federation" sets such tasks as providing the digital economy with competent personnel, supporting talented schoolchildren and students in the field of mathematics, computer science and digital economy technologies, and assisting citizens in mastering the digital literacy and competencies of the digital economy (National Program Passport, 2018).

The most important factor in the advanced training of highly qualified personnel is the focus of educational programs on the long-term tasks of economic sectors and specific enterprises. New training tasks related to the large-scale penetration of digital technologies require the identification of appropriate educational trajectories and the modeling 
of new basic professional educational programs based on the close connection between science and industry (Poverinov et al., 2017).

The priority in the field of education is the project "Modern Digital Educational Environment in the Russian Federation". The aim of the project is high-quality and affordable online education of citizens of the country using digital technologies; creating by 2018 conditions for systemic quality improvement and expansion of continuing education opportunities for all categorizes.

Table 2. The number of students in educational institutions who have been trained in online courses for formal and non-formal education (Priority project passport, 2016)

\begin{tabular}{|c|c|c|c|c|c|c|}
\hline \multirow{2}{*}{ Indicator } & \multirow{2}{*}{$\begin{array}{l}\text { Base } \\
\text { value }\end{array}$} & \multicolumn{5}{|c|}{ Year } \\
\hline & & 2017 & 2018 & 2019 & 2020 & 2025 \\
\hline $\begin{array}{c}\text { The number of students of educational institutions } \\
\text { who have been trained in online courses for formal } \\
\text { and non-formal education, thousand people, } \\
\text { including: }\end{array}$ & 35 & 140 & 1520 & 3050 & 6000 & 11000 \\
\hline $\begin{array}{l}\text { - students of general education organizations, } \\
\text { thousand people; }\end{array}$ & 5 & 50 & 600 & 1500 & 2900 & 6000 \\
\hline $\begin{array}{c}\text { - students of professional educational } \\
\text { organizations and higher educational institutions, } \\
\text { thousand people; }\end{array}$ & 30 & 90 & 920 & 1550 & 3100 & 5000 \\
\hline $\begin{array}{l}\text { The number of students in basic or additional } \\
\text { educational programs who have been trained in } \\
\text { online courses for formal education with a } \\
\text { document confirming the results of training, } \\
\text { thousand people }\end{array}$ & 2 & 20 & 100 & 200 & 300 & 1000 \\
\hline
\end{tabular}

The data in the table indicate plans to increase the number of students in institutions of secondary vocational and higher education who were trained in online courses by 166 times by the year of 2025 .

As a result of the project implementation, an information resource (portal) has now been created that is accessible to all categories of citizens and provides each user with the "one window" principle of access to online courses created by educational levels and online resources for mastering general education subjects developed and implemented by the organizations participating in the project on various online learning platforms (Ilyina et al., 2019).

The portal "Modern Digital Educational Environment in the Russian Federation" today presents 125 universities, 38 platforms (Open BelSU, MOOPED - Online Education Portal of the Volga Regional Center of Competence in the field of Online Learning (RCC), Open Online Academy of the Financial University, e-Siberia - an online learning platform of the Siberian RCC, the National Electronic platform of teacher education, Online education at HSE, Open educational programs and courses at Ural Federal University, VyatSU Open University, Open Polytech, etc.) and 1063 courses yet. The course can be selected by name, field of activity, direction of training, platform, holder, the date of the next start and the language of the course (Russian and English).

The next result of the project was the established system for assessing the quality of online courses and online resources of general education, combining automatic and expert assessment, ensuring the formation of a rating. At the first stage, an examination of online learning platforms that meet the required technical requirements is carried out. Next, an assessment of online courses is carried out: a mandatory assessment of an online course, a voluntary substantive assessment and a continuous assessment by users. The results of all checks are recorded in the passport of the online course. In addition to the description of the online course, its rating, the number of students, marks of passing examinations, as well as feedback from students and employers are reflected in the same place (Resolution of the Government of the Russian Federation, 2014).

The priority project was tasked with creating an infrastructure aimed at training teachers and administrative staff, spreading the experience of introducing successful methods and practices of online learning, tracking the dynamics of creating a digital educational environment. Today there are ten Regional Centers of Competence in the field of online learning: St. Petersburg Polytechnic University of Peter the Great - North-West RCC; Baltic Federal University. I. Kant - Baltic RCC; Siberian Federal University - Siberian RCC; South Federal University - South RCC; 
Far Eastern Federal University - Far Eastern RCC; Moscow State University named after MV Lomonosov on the basis of the branch of Moscow State University in the city of Sevastopol; Volga State University of Technology (Volgatech) - Volga Regional Center of Regional Information Center; Tomsk State University - Tomsk Regional Center; Tula State University - Tula RCC; Tyumen State University - Tyumen Regional Center for Political Studies (Official site of modern digital educational environment, 2019).

The next task of the project is to improve the qualifications of teachers in the development, use and examination of online courses. Today, thirty online courses are hosted on the OpenProfession online learning platform.

The result of the project will be the creation of conditions for the continuous development of the competencies of teachers and specialists. Within the individual trajectories of training teachers and specialists, online courses will be used. There will be an ongoing exchange of experience in the development and use of online courses (Priority project passport, 2016).

\subsection{Threats to the Digital Revolution}

With the development of the economy of the new technological structure, information and personnel become the main driving force. At the same time, the digitization of the entire system of human life and society creates, in addition to progress, a number of threats: rising unemployment; further polarization of society and increasing inequality; risks and challenges of cyber security; the increasing threat of Internet fraud, virus injection, increased hacking and terrorism; a new round of cybercrime, terrorism and organized crime (Petrov, 2019).

According to a RAEC study, the number of cyber-attacks increases every year, in 2016, about $30 \%$ of companies were subjected to cyber-attacks. In this regard, special attention is paid to ensuring information security, which is determined by the competence of developers and relevant specialists, the degree of mastery of leading security practices, and the constant increase in the level of skills adequate to changing types of information threats.

Due to the highest level of competition in the world space, there is a high probability of information threats from foreign countries, often pursuing not only economic, but also political and other goals. At the international level, the decision is the collective conclusion of multilateral cybersecurity agreements by countries on the imposition of a sanction policy against violating countries and countries ignoring accession to the agreement.

For Russia, an important aspect of reducing cyber threats is active import substitution: the transition from foreign software to domestic. Of course, due to the lag of Russia in the field of information and communication technologies, it is quite difficult to completely replace imported technologies with our own production across the entire spectrum of industries. However, ensuring national security necessitates a transition to domestic developments, primarily in the system of state authorities, where foreign operating systems are still used. At present, a pilot project of the Ministry of Communications and the transition to domestic software is being implemented.

In addition to the threats to information security, the development of the digital era may lead to an increase in criminal activity on money laundering through cryptocurrency, illegal business activities, tax evasion. In this case, emphasis should be placed on the development of a system for identifying users, technical means of control and on improving the legislative framework.

\section{Conclusion}

Summarizing the above, we note that the development of the digital economy is a strategically important area of economic growth and national security of our country. However, in order to achieve competitive advantages in this area a number of tasks should be solved. Russia needs to achieve an average annual growth rate of the digital economy of developed countries, in connection with which import substitution in the IT sector, the transition from custom software production to exporting licensed products, expanding market share in leading countries, which will contribute to accelerating the development of digital economy. In addition, a high role in the implementation of the Russian potential will be played by financing programs for the development of digital infrastructure, advanced technologies, improving the education system in accordance with changing challenges and threats, training qualified personnel, and encouraging the increased use of innovative digital technologies.

\section{References}

Bąk, T., Kardis, M., Valco, M., Kalimullin, A. M. \& Galushkin, A. A. (2019). A philosophical-sociological diagnosis of youth subcultures in the context of social changes. XLinguae, 12(2), 163-185.

Bunakov, O. A., Zaitseva, N. A., Larionova, A. A., Chudnovskiy, A. D., Zhukova, M. A. \& Zhukov, V. A. (2015). Research on the evolution of management concepts of sustainable tourism and hospitality development in the regions. Journal of Sustainable Development, 8(6), 39-44. 
Cao, Y., Kirilova, G. I. \& Grunis, M. L. (2017). Cooperative Research Projects of Master's Students (Education Programs) in the Open Informational Educational Environment. EURASIA Journal of Mathematics, Science and Technology Education, 13(7), 2859-2868.

Chen, F., Gorbunova, N. V., Masalimova, A. R. \& Bírová, J. (2017). Formation of ICT-Competence of Future University School Teachers. EURASIA Journal of Mathematics, Science and Technology Education, 13(8), 4765-4777.

Danilov, I. P., Ladykova, T. I., Morozova, N. V., Ilyina, E. A. \& Nikiforov, Y. G. (2017). Re-industrialization and innovative development of Russia. Journal of Advanced Research in Law and Economics, 8(2), 437-443.

Erdyneeva, K. G., Vasilyeva, K. K., Krysova, E. V., Nikonova, T. V., Fatikhova, L. E., Klimenko, T. I., Zaitseva, N. A. \& Marfina, L. V. (2016). The mechanism of state regulation of regional services markets as an imperative to reduce territorial socio-economic disparities. International Review of Management and Marketing, 6(2), 274-280.

Grebenkina, S. A. (2018a). The economy of "new era". In the collection: Knowledge Economy: innovation ecosystem and new industrialization of the region. Krasnodar, 12-20.

Grebenkina, S. A. (2018b). The development of digital economy in the Russian Federation. In the collection: Management and marketing: theory and practice. Cheboksary, 580-586.

Grigorieva, S. (2018). Transformational administration as form of innovative development of the construction organization. MATEC Web of Conferences, 251, 114-125.

Ilyina, E. A., Gorshkova, N. K. \& Grigorieva, S. V. (2019). Development of digital educational environment in Russia. Cheboksary, 116-121.

Keshelava, A. V. (2017). Introduction to the "Digital" Economy. Moscow: VNIIGeosystem.

Khalin, V. G. \& Chernova, G. V. (2018). Digitalization and its impact on the Russian economy and society: advantages, challenges, threats and risks. Management Consulting, 10(118). URL: https://cyberleninka.ru/article/n/tsifrovizatsiya-i-ee-vliyanie-na-rossiyskuyu-ekonomiku-i-obschestvo-preimusch estva-vyzovy-ugrozy-i-riski. (Accessed 16 June 2019).

Khusainova, S. V., Matveyeva, L. V., Ermilova, L. P., Yakushevskaya K. N., Kolomiychenko, L. V. \& Mashkin, N. A. (2018). Adaptive model of psychological and pedagogical accompany of student professional training. Espacios, 39(05), 22.

Kong, Y., Kayumova, L. R. \& Zakirova, V. G. (2017). Simulation Technologies in Preparing Teachers to Deal with Risks. EURASIA Journal of Mathematics, Science and Technology Education, 13(8), 4753-4763.

Konysheva, A. V. \& Ibragimova, E. N. (2017). Training of Engineers in Mathematics at University on the Basis of the Information Cybernetic Approach. EURASIA Journal of Mathematics, Science and Technology Education, 13(8), 4379-4391.

Kupriyanovskiy, V. P. (2016). Digital economy - "The smart way to work". International Journal of Open Information Technologies, 2, 26-33.

Kushnir, M. (2017). Digital Educational Environment. Online Directory, June $13 . \quad$ URL: https://medium.com/direktoria-online/the-digital-learning-environment-f1255d06942a. (Accessed 16 June 2019).

Kuzmin, V. (2016). Digital environment on the calendar. Dmitry Medvedev - on the priorities of education in Russia. Russian Newspaper, 189(7057), 234-247.

Kvon, G. M., Vaks, V. B., Masalimova, A. R., Kryukova, N. I., Rod, Y. S., Shagieva, R. V. \& Khudzhatov, M. B. (2018). Risk in Implementing New Electronic Management Systems at Universities. Eurasia Journal of Mathematics, Science and Technology Education, 14(3), 891-902.

Lebedeva, O., Bykova, S., Masalimova, A. R., Sokolova, N. L. \& Kryukova, N. I. (2018). Peculiarities of developing high school students' lexical skills by means of the programmed learning technology. XLinguae, 11(1), 186-202.

Lin, K., Sokolova, A. N. \& Vlasova, V. K. (2017). Methodological Potential of Computer Experiment in Teaching Mathematics at University. Eurasia Journal of Mathematics, Science and Technology Education, 13(7), 3539-3552.

Lubnina, A. A., Shinkevich, M. V., Ashmarin, S. I., Zaitseva, N. A., Sayfutdinova, G. B. \& Ishmuradova, I. I. (2016). Resource saving innovative forms of the industrial enterprises. International Journal of Economics and Financial 
Issues, 6(2), 479-483.

Martins, V. F., Sampaio, P. N. M., Cordeiro, A. J. A. \& Viana, B. F. (2018). Implementing a Data Network Infrastructure Course using a Problem-based Learning Methodology. Journal of Information Systems Engineering \& Management, 3(2), 10.

Masalimova, A. R., Levina, E. Y., Platonova, R. I., Yakubenko, K., Yu., Mamitova, N. V., Arzumanova, L. L., Grebennikov, V. V. \& Marchuk, N. N. (2017). Cognitive Simulation as Integrated Innovative Technology in Teaching of Social and Humanitarian Disciplines. EURASIA Journal of Mathematics, Science and Technology Education, 13(8), 4915-4928.

Masalimova, A. R., Mikhaylovsky, M. N., Grinenko, A. V., Smirnova, M. E., Andryushchenko, L. B., Kochkina, M. A. \& Kochetkov, I. G. (2019). The Interrelation between Cognitive Styles and Copying Strategies among Student Youth. Eurasia Journal of Mathematics, Science and Technology Education, 15(4). em1695. https://doi.org/10.29333/ejmste/103565.

Merkulova, V. A., Voronina, M. V. \& Tretyakova, Z. O. (2018). Designing mountain drawings with the help of computer-aided design (CAD). International Conference on Construction, Architecture and Technosphere Safety 2018, ICCATS 2018: IOP Conference Series: Materials Science and Engineering, 451(1), article number 012122 .

Monitoring of the Information Society Development in the Russian Federation. (2018). Indicators of information society development in the Russian Federation. URL: http://www.gks.ru/wps/wcm/connect/rosstat_main/rosstat/ru/statistics/science_and_innovations/it_technology/. (Accessed 16 June 2019).

Mukhametshin, R. Z., Kryukova, N. I., Beloborodova, A. V., Grinenko, A. V. \& Popova, O. V. (2019). Implementation of efficient energy policy in Russia: Energy consumption monitoring and problem analysis. International Journal of Energy Economics and Policy, 9(4), 224-232.

National Program Passport. (2018). Digital Economy of the Russian Federation (approved by the Presidium of the Presidential Council for Strategic Development and National Projects, minutes dated December 24, 2018 № 16). URL: http://www.consultant.ru/document/cons_doc_LAW_319432/. (Accessed 16 June 2019).

Nesterenko, E. A. \& Kozlova, A. S. (2018). Directions of development of the digital economy and digital technologies in Russia, 2(31). URL: https://cyberleninka.ru/article/n/napravleniya-razvitiya-tsifrovoy-ekonomiki-i-tsifrovyh-tehnologiy-v-rossii. (Accessed 16 June 2019).

Official Site of Modern Digital Educational Environment. (2019). URL: https://online.edu.ru/ru. Accessed 16 June 2019.

Petrov, A. A. (2019). Opportunities and directions of development of digital economy in Russia and blocking factors of its development. Actual problems of Russian law, 3(100). URL: https://cyberleninka.ru/article/n/vozmozhnosti-i-napravleniya-razvitiya-tsifrovoy-ekonomiki-v-rossii-i-blokiruy uschie-faktory-ee-razvitiya. (Accessed 16 June 2019).

Petrovskaya, M. V., Zaitseva, N. A., Bondarchuk, N. V., Grigorieva, E. M. \& Vasilieva, L. S. (2016). Scientific methodological basis of the risk management implementation for companies' capital structure optimization. IEJME-Mathematics Education, 11(7), 2571-2580.

Pomelov, V. B., Khairutdinova, R. R. \& Kryukova, N. I. (2018). Lexical material of regional content in the process of implementing the communicative approach in teaching English to students of non-linguistic specialties. XLinguae, $11(1), 136-151$.

Poverinov, I. E., Kovalev, V. G. \& Shchiptsova, A. V. (2017). Organization of engineering personnel training for potential ways of economic development. Higher education in Russia, 7, 106-112.

Priority project passport (2016). Modern digital educational environment in the Russian Federation (approved by the Presidium of the Presidential Council for Strategic Development and Priority Projects, minutes dated October 25, 2016 № 9). URL: http://www.consultant.ru/document/cons_doc_LAW_216432/. (Accessed 16 June 2019).

Puspitasari, L., In'am, A. \& Syaifuddin, M. (2019). Analysis of Students' Creative Thinking in Solving Arithmetic Problems. International Electronic Journal of Mathematics Education, 14(1), 49-60. https://doi.org/10.12973/iejme/3962 
Rasooli, M. \& Abedini, M. (2017). The Relationship between Organizational Support and Job Satisfaction of Experts and Managers of Islamic Azad University of Qeshm and Subsidiaries (International Units, Medical, Sama, Hormuz and Khamir). Dutch Journal of Finance and Management, 1(2), 42. https://doi.org/10.29333/djfm/5818

Resolution of the Government of the Russian Federation. (2014). from 15.04.2014 No. 313 (ed. from 23.05.2009) On approval of the state program of the Russian Federation "Information society. URL: http://www.consultant.ru/document/cons_doc_LA-W_162184/. (Accessed 16 June 2019).

Sailaukyzy, A., Shakuova, R., Sak, K. \& Lebedeva, T. (2018). Contemporary view to the history of Kazakhstan's democratic journalism and publicism. Opción, 34(85-2), 774-799.

Selivanova, O. G., Gromova, C. R. \& Mashkin, N. A. (2018). Improving student motivation for learning the second foreign language. XLinguae, 11(1), 218-229.

Shcherbakov, V. S., Makarov, A. L., Buldakova, N. V., Butenko, T. P., Fedorova, L. V., Galoyan, A. R. \& Kryukova, N. I. (2017). Development of higher education students' creative abilities in learning and research activity. Eurasian Journal of Analytical Chemistry, 12(5), 765-778.

Shchiptsova, A. V. (2018). Improving the system of qualified personnel training and conducting interdisciplinary research and development demanded by the digital economy. In the collection "The state and development prospects of IT education". Cheboksary, 13-17.

Sizova, Z. M., Semenova, T. V., Naydenova, N. N., Narbut, V. V., Chelyshkova, M. B. \& Masalimova A. R. (2019). Fairness Principle in Accreditation of Health Specialists: The Differential Item Functioning Method. Eurasia Journal of Mathematics, Science and Technology Education, 15(9), em1749.

Strategy for the development of the information technology industry in the Russian Federation for 2014-2020 and for the future until 2025. (2013). Approved by the decree of the Government of the Russian Federation of 1 November 2013, No. 2036-R. URL: http://www.consultant.ru/document/cons_doc_LAW_154161/ (Accessed 16 June 2019).

Tastan, S. B. \& Davoudi, S. M. M. (2015). A Research on The Relevance Of Intellectual Capital And Employee Job Performance As Measured With Distinct Constructs Of In-Role And Extra-Role Behaviors. Indian Journal of Science and Technology, 8(7), 724-734.

The decree of the President of the Russian Federation. (2017). From May 9, 2017 No. 203 "On the Strategy of the development of the information society in the Russian Federation for 2017 - 2030". http://www.consultant.ru/document/cons_doc_LAW_216363/ (Accessed 16 June 2019).

Usak, M. \& Masalimova, A. R. (2019). Mentoring on science teacher education in Russia and international perspectives. Journal of Baltic Science Education, 18(3), 320-322.

Vayndorf-Sysoeva, M. E. \& Subocheva, M. L. (2018). "Digital education" as a system-forming category: approaches to definition. Bulletin of MRSU. Series: Pedagogy, 3. URL: https://cyberleninka.ru/article/n/tsifrovoe-obrazovanie-kak-sistemoobrazuyuschaya-kategoriya-podhody-k-opre deleniyu. (Accessed 16 June 2019).

Velieva, S. V., Mashkin, N. A., Khairullina, E. R., Semenova, T. N., Varlamova, M. E., Guseva, T. S. \& Dolgasheva, M. V. (2018). University student professional selfactualization: Context of personality subjectivity. Espacios, $39(20), 12$.

Vinogradova, G. A., Akhmadieva, R. S., Konovalova, V. M., Spirina, E. V., Kalugina, O. A., Erdyneeva, K. G., Popova, N. N. \& Mashkin, N. A. (2018). Releasers as factor of student ecological focus formation. Ekoloji, 27(106), 1409-1415.

Yudina, T. N. (2016). Understanding the digital economy. Theoretical Economics, 3, 12-16.

Zaitseva, N. A., Larionova, A. A., Gornostaeva, Z. V., Malinina, O. Y., Povalayeva, V. A., Vasenev, S. L., Skrynnikova, I. A. \& Ersozlu, A. (2017). Elaboration of the methodology for assessing the development of managerial competences in university students taught with the use of case-technologies. Eurasia Journal of Mathematics, Science and Technology Education, 13(11), 7339-7351. 